\title{
FLEXURAL BEHAVIOR AND SIZE EFFECT OF FULL SCALE REINFORCED LIGHTWEIGHT CONCRETE BEAM
}

\author{
Chung-Hao Wu \\ Department of Civil Engineering, National Chung-Hsing University, Taichung City, Taiwan, R.O.C. \\ Yu-Cheng Kan \\ Department of Construction Engineering, Chaoyang University of Technology, Wufong Township Taichung County, \\ Taiwan, R.O.C. \\ Chung-Ho Huang \\ Department of Civil Engineering, Dahan Institute of Technology, Sincheng Township Hualien County, Taiwan, R.O.C. \\ Tsong Yen \\ Department of Civil Engineering, National Chung-Hsing University, Taichung City, Taiwan, R.O.C., \\ tyen@dragon.nchu.edu.tw \\ Li-Huai Chen \\ Department of Construction Engineering, Chaoyang University of Technology, Wufong Township Taichung County, \\ Taiwan, R.O.C.
}

Follow this and additional works at: https://jmstt.ntou.edu.tw/journal

Part of the Civil and Environmental Engineering Commons

\author{
Recommended Citation \\ Wu, Chung-Hao; Kan, Yu-Cheng; Huang, Chung-Ho; Yen, Tsong; and Chen, Li-Huai (2011) "FLEXURAL BEHAVIOR AND \\ SIZE EFFECT OF FULL SCALE REINFORCED LIGHTWEIGHT CONCRETE BEAM," Journal of Marine Science and \\ Technology: Vol. 19: Iss. 2, Article 4. \\ DOI: $10.51400 / 2709-6998.2147$ \\ Available at: https://jmstt.ntou.edu.tw/journal/vol19/iss2/4 \\ This Research Article is brought to you for free and open access by Journal of Marine Science and Technology. It has been \\ accepted for inclusion in Journal of Marine Science and Technology by an authorized editor of Journal of Marine Science and \\ Technology.
}


FLEXURAL BEHAVIOR AND SIZE EFFECT OF FULL SCALE REINFORCED LIGHTWEIGHT CONCRETE BEAM

Acknowledgements

The authors are grateful for the financial supports from the Architecture and Building Research Institute in Taiwan. Professor Fuh-Min Fang is appreciated for his editorial assistance. 


\title{
FLEXURAL BEHAVIOR AND SIZE EFFECT OF FULL SCALE REINFORCED LIGHTWEIGHT CONCRETE BEAM
}

\author{
Chung-Hao Wu*, Yu-Cheng Kan**, Chung-Ho Huang***, Tsong Yen*, \\ and Li-Huai Chen**
}

Key words: lightweight aggregate concrete, beam, flexural behavior, size effect.

\begin{abstract}
This article presents the results of experimental investigations on the size effect and the flexural behavior of full size reinforced concrete beams with lightweight aggregate and normal aggregate. The lightweight aggregate (LWA) was manufactured with fine sediments collected from the Shih-Men Reservoir in Taiwan. A total of 6 flexure beams with various reinforcement ratios (from $0.33 \%$ to $1.3 \%$ ) and 6 size-effect beams with various dimensions were fabricated and tested. The designed compressive strength of concrete was $34 \mathrm{MPa}$.

Test results indicated that the reinforced lightweight aggregate concrete (LWAC) beams had a similar load capacity and failure mode as those of normal weight concrete (NWC) beams, but demonstrated larger ultimate deflections and curvature ductility. The curvature ductility of both types of concrete beam decreased as the reinforcement ratio increased. On the other hand, an increase of the beam dimension lead to increases of the load and deflection at the yielding strength and ultimate strength, but reduced the ultimate deflection ratio for both types of concrete beams. In addition, the ultimate deflection-to-span ratio varied from $1 / 115$ to $1 / 150$ (23\% reduction) as the effective depth increased from $300 \mathrm{~mm}$ to $600 \mathrm{~mm}$ for the NWC beams and from $1 / 84$ to $1 / 188$ (55\% reduction) for the LWAC beams, respectively. This reveals that the decay of ultimate deflection ratio of the LWAC beams due to the increase of beam size is more significant than that of the NWC beams.
\end{abstract}

Paper submitted 11/26/09; revised 01/29/10; accepted 02/06/10. Author for correspondence: Tsong Yen (e-mail: tyen@dragon.nchu.edu.tw).

*Department of Civil Engineering, National Chung-Hsing University, Taichung City, Taiwan, R.O.C.

**Department of Construction Engineering, Chaoyang University of Technology, Wufong Township Taichung County, Taiwan, R.O.C.

***Department of Civil Engineering, Dahan Institute of Technology, Sincheng Township Hualien County, Taiwan, R.O.C.

\section{INTRODUCTION}

There are more than 70 reservoirs in Taiwan. Most of the reservoirs face significant sediment problem that seriously threaten service lives of reservoirs. Architecture and Building Research Institute (ABRI) and National Science Council, two leading research arms in Taiwan, have been assigned by government to tackle the problem. In response to government's call, a research team was organized by authors at National Chung Hsing University in 2003 to solve the sedimentary problem. Since the reservoir silt comes from the weathered rocks of clay, shale and slate etc., which can be used as raw materials of LWA. A practical procedure involving pumping, hauling, air-drying, crushing/grinding, and sintering was proposed by the team in 2004 and the proposal was accepted in the same year. Within 3 years the team successfully manufactured qualitative LWA from sediment excavated from the Shih-Men reservoir $[8,13]$.

Engineering properties of lightweight aggregate concrete made with the LWA were experimentally measured and the results have met the ACI 318-08 Building Code Requirements $[8,14]$. However, the mechanical properties of LWAC differ significantly from those of normal weight concrete, mainly attributed to high porosity of LWA, which causes high water absorption rate and smaller modulus of elasticity of concrete thus made $[4,11,15]$.

In flexure, a number of researches have been conducted related to the behavior of reinforced LWAC beam [1-3, 9, 12], and the current major codes of practices (ACI 318, BS 8110 and EC 2) contain rules for the design of LWAC members. But a thorough search of existing literatures reveal that only rare reports were dealt with full size structural test, and the rules are mainly based on research work conducted in the 1960s, subsequent to which material technology has advanced significantly. It is also seen that those design regulation relating to LWAC were mostly directly modified from those of normal concrete. Therefore, there is a need to critically reassess the existing code provisions in the perspective of the advances in material technology during the last two decades, especially to figure the structural behavior of LWAC element through full-scaled tests. 
$\log \left(\sigma_{N} / B f_{t}\right)$

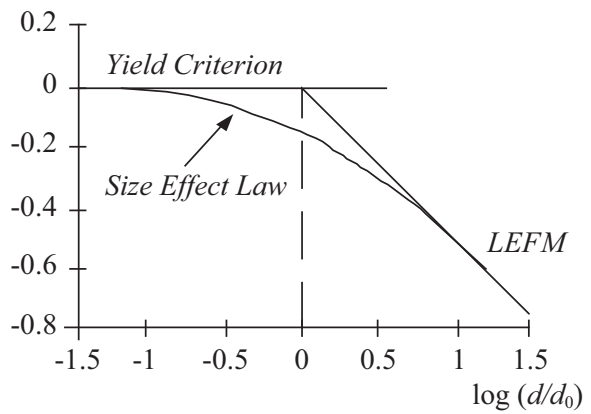

Fig. 1. Size effect law proposed by Bazant. [16]

On the other hand, recent researches have revealed that the failure of concrete is dominated by the fracture propagation process, rather than the strength criterion. Researches in nonlinear fracture mechanics area in the past have successfully predicted the size effect of the concrete structure $[5-6,16]$. Bazant proposed a model to predict the size effect of concrete beam, as described in Eq. (1) (Fig. 1):

$$
\begin{gathered}
\sigma_{n}=\frac{B f_{t}}{\sqrt{1+\beta}} \\
\beta=\frac{d}{d_{0}}
\end{gathered}
$$

where $\sigma_{n}$ is the nominal strength, $d$ is the depth of specimen, $f t$ is the tensile strength of the material, $B$ and $d_{0}$ are empirical constants.

For reinforced concrete, Carpinteri [7] proposed a brittleness number corresponding to a transition between ductile $(\rho>$ $\left.\rho_{\text {min }}\right)$ and brittle $\left(\rho<\rho_{\text {min }}\right)$ failures for concrete. The predicted values of $\rho_{\text {min }}$ for different types of concrete are compared to the values given by ACI 318 and EC 2. It is seen that the minimum reinforcement ratio decreases with increasing size of the beam. Although LWAC tends to be more brittle, the research on the fracture behavior of LWAC has been limited. It is felt that the study of the size effect in LWAC may help to understand the behavior of LWAC and predict load-bearing capacities of different sizes of LWAC beams. Hence, an experimental research was carried out to examine the size effect of LWAC beam.

\section{EXPERIMENTAL PROGRAM}

The present experimental program consists of two groups of beams, one group was prepared for flexural test and the other for size effect test. Each group contained two series, each series 3 beams, of reinforced concrete beams. The first series was made with sedimentary lightweight aggregate and the other was made with NWC. In flexural experiment, the $\mathrm{RC}$ beams of $250 \mathrm{~mm}$ wide, $400 \mathrm{~mm}$ deep, and $4600 \mathrm{~mm}$ long

\begin{tabular}{|c|c|c|c|c|c|c|}
\hline Concrete & series & $\begin{array}{c}\text { beam size } \\
(\mathrm{mm})\end{array}$ & $\begin{array}{l}\text { length } \\
(\mathrm{mm})\end{array}$ & $\rho(\%)$ & \begin{tabular}{|l|} 
com. rebar/ \\
tensile rebar
\end{tabular} & $\begin{array}{l}\text { shear } \\
\text { rebar }\end{array}$ \\
\hline \multirow{3}{*}{ LWAC } & FL1 & $250 \times 400$ & \multirow{3}{*}{4600} & 0.33 & $2 \# 3 / 1 \# 6$ & $8 \# 3$ \\
\hline & FL2 & $250 \times 400$ & & 0.97 & $2 \# 3 / 3 \# 6$ & $16 \# 3$ \\
\hline & FL3 & $250 \times 400$ & & 1.3 & $2 \# 3 / 4 \# 6$ & $18 \# 3$ \\
\hline \multirow{3}{*}{ NWC } & FN1 & $250 \times 400$ & \multirow{3}{*}{4600} & 0.33 & $2 \# 3 / 1 \# 6$ & $8 \# 3$ \\
\hline & FN2 & $250 \times 400$ & & 0.97 & $2 \# 3 / 3 \# 6$ & $16 \# 3$ \\
\hline & FN3 & $250 \times 400$ & & 1.3 & $2 \# 3 / 4 \# 6$ & $18 \# 3$ \\
\hline
\end{tabular}

Table 1. Detail of flexure test beams.

Note: $\mathrm{FL}=$ flexure test series of LWAC beam

$\mathrm{FN}=$ flexure test series of NWC beam

Table 2. Detail of size effect test beams.

\begin{tabular}{|c|c|c|c|c|c|c|c|}
\hline \multirow{3}{*}{ Concrete } & series & \multicolumn{7}{|c|}{ beam size (mm) } \\
\cline { 3 - 8 } & & $\begin{array}{c}\text { width } \\
\text { (b) }\end{array}$ & $\begin{array}{c}\text { depth } \\
\text { (h) }\end{array}$ & $\begin{array}{c}\text { effective } \\
\text { depth (d) }\end{array}$ & $\begin{array}{c}\text { tensile } \\
\text { rebar }\end{array}$ & $\begin{array}{c}\text { span } \\
\text { (s) }\end{array}$ & $\begin{array}{c}\text { length } \\
\text { (L) }\end{array}$ \\
\hline \multirow{4}{*}{ LWAC } & DL1 & 250 & 400 & 300 & $2-\# 4$ & 1800 & 2400 \\
\cline { 2 - 8 } & DL2 & 375 & 550 & 450 & $\begin{array}{c}1-\# 5 \\
4-\# 4\end{array}$ & 2700 & 3300 \\
\cline { 2 - 8 } & DL3 & 500 & 700 & 600 & $6-\# 5$ & 3600 & 4200 \\
\hline \multirow{4}{*}{ NWC } & DN1 & 250 & 400 & 300 & $2-\# 4$ & 1800 & 2400 \\
\cline { 2 - 8 } & DN2 & 375 & 550 & 450 & $\begin{array}{c}1-\# 5 \\
4-\# 4\end{array}$ & 2700 & 3300 \\
\cline { 2 - 8 } & DN3 & 500 & 700 & 600 & $6-\# 5$ & 3600 & 4200 \\
\hline
\end{tabular}

Note: $\mathrm{DL}=$ size effect test series of LWAC beam

$\mathrm{DN}=$ size effect test series of NWC beam

as given in Table 1 were cast. The LWAC specimens are referred to FL series and the NWC specimens are referred to FN series. All beams were designed as under-reinforced beams. The primary design variables were reinforcement ratios of $0.33 \%, 0.97 \%$, and $1.3 \%$. All beams were equipped with adequate stirrup to prevent from shear failure. Fig. 2 gives dimensions and reinforcement details for flexural beams. In size effect test, three dimensions of beam with geometrical similarity were adopted as shown in Table 2. The LWAC specimens and the NWC specimens are referred to DL series and DN series, respectively. Fig. 3 gives dimensions and reinforcement details for size-effect beams. Each beam was arranged with minimum reinforcements according to ACI code. No stirrup was used in all beams. The compressive strength of both LWAC and NWC was designed as $34 \mathrm{MPa}$.

\section{Materials and Mix Proportions}

The mix proportions for lightweight and normal weight concrete are presented in Table 3. The materials used in the mix were Ordinary Portland Cement (ASTM Type 1), river sand, crushed gravel, course lightweight aggregate and highrange water-reducing agent (superplasticizer). The coarse lightweight aggregate used, as shown in Fig. 4, was made with fine sediments collected from the Shin-Men Reservoir in Taiwan. It has grain sizes of 9.5-4.74 mm, tube strength of 7.2 $\mathrm{MPa}$, particle density of $1.64 \mathrm{~g} / \mathrm{cm}^{3}$ and water absorption after 


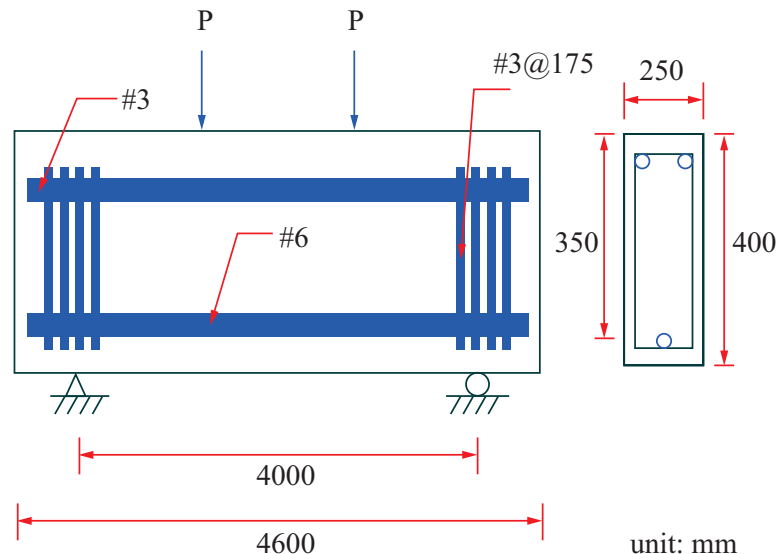

(a) $\rho=0.33 \%$

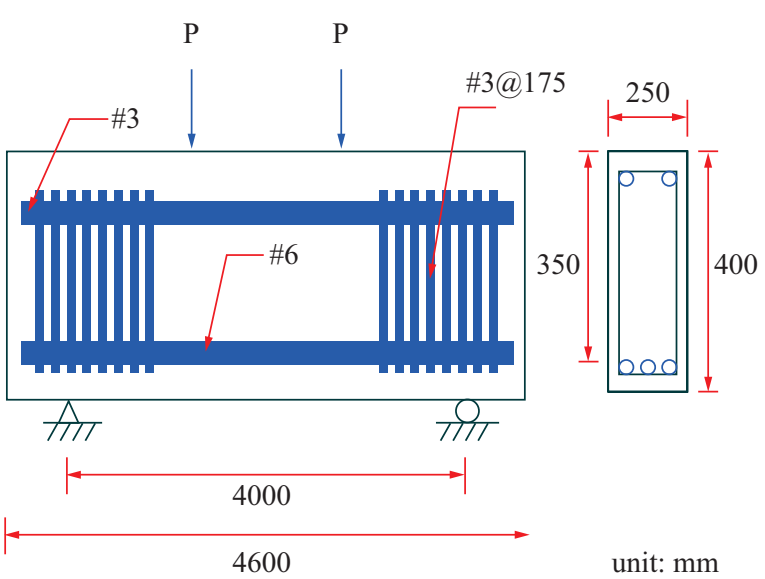

(b) $\rho=0.97 \%$

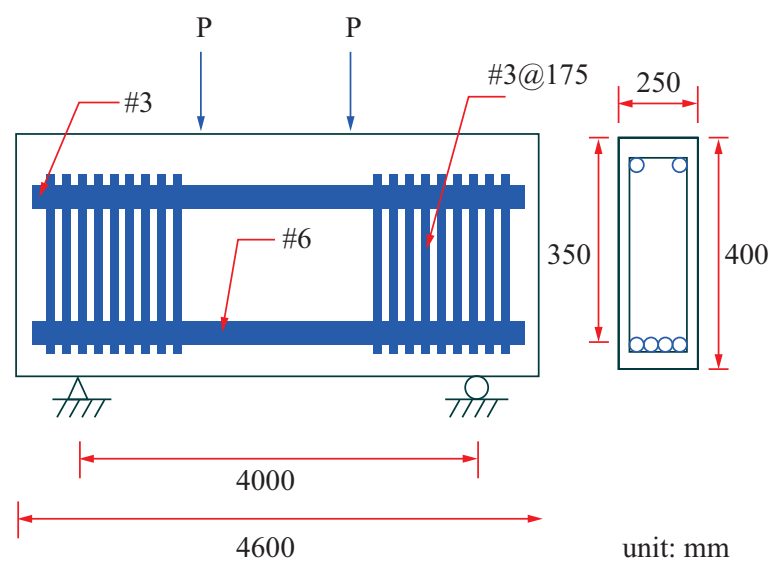

(c) $\rho=1.29 \%$
Table 3. Mix proportion of concretes.

\begin{tabular}{|c|c|c|c|}
\hline \multicolumn{2}{|c|}{ Mixture $\left(\mathrm{kg} / \mathrm{m}^{3}\right)$} & LWAC & NWC \\
\hline $\mathrm{W} / \mathrm{C}$ & & 0.57 & 0.63 \\
\hline Water & $\mathrm{kg}$ & 200 & 221 \\
\hline Cement & $\mathrm{kg}$ & 350 & 350 \\
\hline Aggregate & $\mathrm{kg}$ & 572 & 845 \\
\hline Sand & $\mathrm{kg}$ & 857 & 851 \\
\hline S.P. & $\mathrm{kg}$ & 4.9 & 3.5 \\
\hline Air & $\%$ & 3.5 & 2.0 \\
\hline \multicolumn{2}{|c|}{ Compressive strength (MPa) } & 34.2 & 32.3 \\
\hline
\end{tabular}

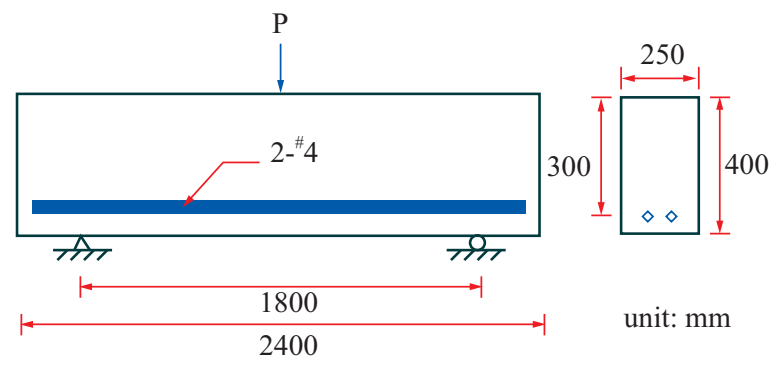

(a) beam size: $250 \mathrm{~mm} \times 300 \mathrm{~mm} \times 1800 \mathrm{~mm}(\mathrm{~b} \times \mathrm{h} \times \mathrm{S})$

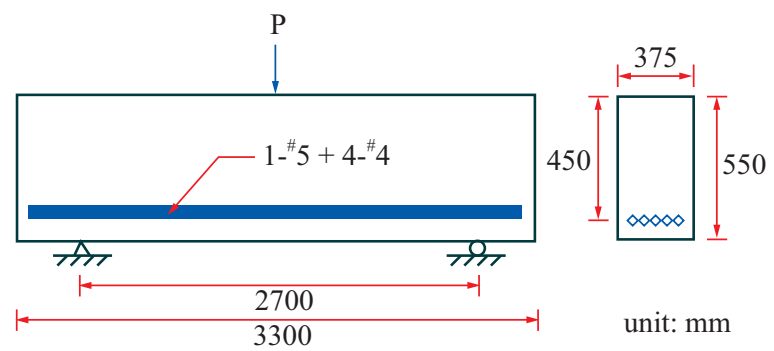

(b) beam size: $375 \mathrm{~mm} \times 450 \mathrm{~mm} \times 2700 \mathrm{~mm}(\mathrm{~b} \times \mathrm{h} \times \mathrm{S})$

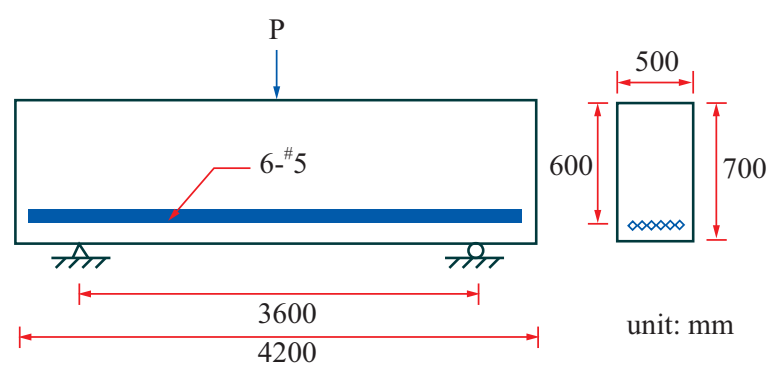

(c) beam size: $500 \mathrm{~mm} \times 600 \mathrm{~mm} \times 3600 \mathrm{~mm}(\mathrm{~b} \times \mathrm{h} \times \mathrm{S})$

Fig. 3. Detail of size effect test beams.

Fig. 2. Detail of flexure test beams.

30 minutes and 24 hours of $5.3 \%$ and $9.2 \%$, respectively. In LWAC the natural river sand was used as fine aggregate. The normal sand has specific gravity of 2.64, water absorption of $1.36 \%$ and fineness modulus of 2.80 . Crushed river siliceous gravel was used as coarse aggregate. It has grain size of $9.5-4.74 \mathrm{~mm}$, specific gravity of 2.64 and water absorption of $0.94 \%$.
Three sizes of deformed bar (\#4, \#5, \#6) were used for all longitudinal reinforcement. The stirrup used was \#3 deformed bar. Table 4 gives the mechanical properties of rebars used.

\section{Mixing and Fabrication of Specimens}

To prepare LWAC mixtures, a careful observation on the amount of water absorbed by the LWA during mixing and 
Table 4. Mechanical properties of reinforcement.

\begin{tabular}{|c|c|c|c|}
\hline bar size & $\begin{array}{c}\text { Nominal } \\
\text { diameter }(\mathrm{mm})\end{array}$ & $\begin{array}{c}\text { Yield strength } \\
f_{y}(\mathrm{MPa})\end{array}$ & $\begin{array}{c}\text { Ultimate strength } \\
f_{u}(\mathrm{MPa})\end{array}$ \\
\hline$\# 3$ & 9.5 & 408 & 596 \\
\hline$\# 4$ & 12.7 & 385 & 474 \\
\hline$\# 5$ & 15.9 & 331 & 484 \\
\hline$\# 6$ & 19.1 & 479 & 630 \\
\hline
\end{tabular}

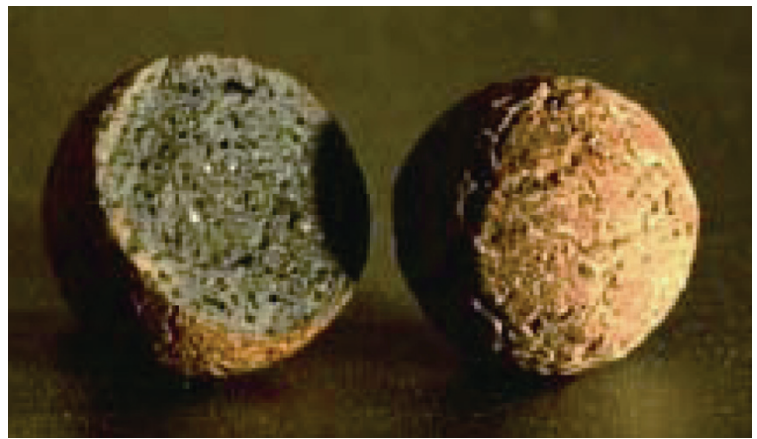

Fig. 4. LWA manufactured from reservoir fine sediments.

placement was exercised. In the mixing process pre-assessed amount of water was slowly added to LWA without presoaking. The amount of added water was computed based on 30 minutes absorption of the same aggregate tested previously. The mixing starts by blending cement, sand, and coarse aggregate for about 120 seconds, and followed by pouring in a premixed water/superplasticizer solution, and continued the mixing process until a uniform mixture was reached, for approximately 90 seconds.

Freshly mixed concrete was then slowly poured in the plywood mold to the half depth of beam across the horizontal surface and followed by controlled vibrations. Immediately after vibration, the second half of the mixture was poured in and subjected to vibrations again to make sure that the concrete was well compacted. The such prepared specimens include 6 full size flexure beams and 6 beams for size effect test. Three control cylinders of $\psi 100 \mathrm{~mm} \times 200 \mathrm{~mm}$ were cast with suitable external vibration for each mixture. After casting, all specimens were covered with polyethylene sheets to prevent the evaporation of water from the concrete surface. The cylinder compressive strength of concrete at the time of beam test is given in Table 3 .

\section{Instrumentation and Test Procedure}

The test beams were simply supported and were subjected to four-point loading and three-point loading for the flexure test and size effect test, respectively. Details of the test setup are shown in Fig. 5 and Fig. 6. Load cell was used for monitoring the load on the test beams. A linear voltage differential transducer (LVDT) was used to monitor the vertical deflection at mid-span of beams. The load tests were performed in dis-

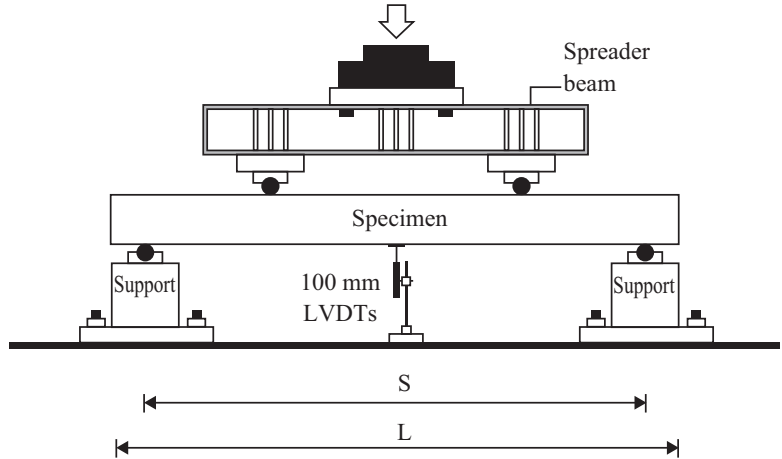

Fig. 5. Flexural test set up.

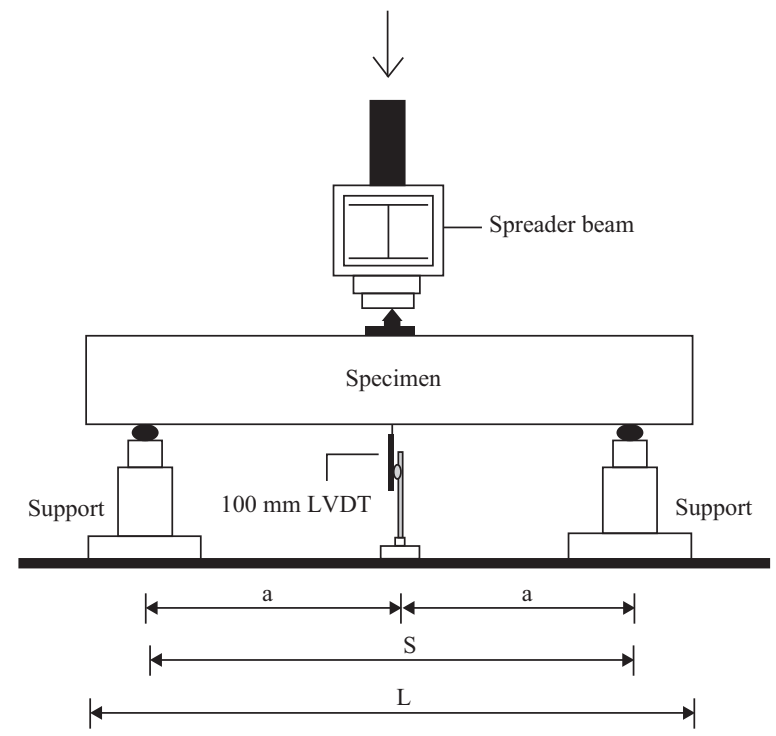

Fig. 6. Configuration of three-point bending load test.

placement control on a MTS testing system with a 100 tons capacity actuator. The beams were loaded incrementally with a displacement rate of $0.05 \mathrm{~mm} / \mathrm{sec}$ until failure. The outputs from the load cell and LVDT were continuously recorded by use of a data acquisition system of the model, KYOWA UCAM-60A. During the tests, the cracking pattern was also monitored.

\section{RESULTS AND DISCUSSION}

\section{Flexure Investigation}

\section{1) Flexure Behavior of LWAC Beam}

The load-deflection curves of the tested beams are shown in Fig. 7. It may be seen that the curves are characterized by four significant events that took place during the loading process to failure. These events can be identified as first cracking of concrete, yielding of tensile reinforcement, crushing of the concrete cover in the compression zone and final collapse of the compressive concrete. The first two events are obviously 
Table 5. Results of flexural load test.

\begin{tabular}{|c|c|c|c|c|c|c|}
\hline \multirow{2}{*}{ Beam number } & \multicolumn{2}{|c|}{ At first cracking } & \multicolumn{2}{|c|}{ At yielding } & \multicolumn{2}{c|}{ At ultimate } \\
\cline { 2 - 7 } & $\begin{array}{c}\text { load } \\
P_{i c}(\mathrm{kN})\end{array}$ & $\begin{array}{c}\text { deflection } \\
\Delta_{i c}(\mathrm{~mm})\end{array}$ & $\begin{array}{c}\text { load } \\
P_{y}(\mathrm{kN})\end{array}$ & $\begin{array}{c}\text { deflection } \\
\Delta_{y}(\mathrm{~mm})\end{array}$ & $\begin{array}{c}\text { load } \\
P_{u}(\mathrm{kN})\end{array}$ & $\begin{array}{c}\text { deflection } \\
\Delta_{u}(\mathrm{~mm})\end{array}$ \\
\hline FL1 & 20 & 1.00 & 68.81 & 19.50 & 75.74 & 70.97 \\
\hline FL2 & 40 & 2.96 & 191.7 & 24.10 & 201.2 & 67.41 \\
\hline FL3 & 40 & 2.14 & 253.9 & 27.30 & 260.2 & 52.17 \\
\hline FN1 & 25 & 1.57 & 63.67 & 16.80 & 67.61 & 64.34 \\
\hline FN2 & 40 & 2.03 & 207.2 & 23.50 & 210.2 & 32.94 \\
\hline FN3 & 40 & 2.46 & 246.4 & 26.24 & 247.3 & 44.87 \\
\hline
\end{tabular}

Table 6. Results of measured moment and analyzed curvature.

\begin{tabular}{|c|c|c|c|c|c|c|c|}
\hline \multirow[b]{2}{*}{ Beam number } & \multicolumn{2}{|c|}{ At initial cracking } & \multicolumn{2}{|c|}{ At yielding } & \multicolumn{2}{|c|}{ At ultimate } & \multirow{2}{*}{$\begin{array}{c}\text { Curvature ductility ratio } \\
\qquad \mu_{\psi}=\psi_{u} / \psi_{y}\end{array}$} \\
\hline & $\begin{array}{c}\text { moment } \\
M_{i c}(\mathrm{kN}-\mathrm{m})\end{array}$ & $\begin{array}{c}\text { curvature } \\
\mathscr{\psi}_{i c}\left(10^{-3}\right)\end{array}$ & $\begin{array}{c}\text { moment } \\
M_{y}(\mathrm{kN}-\mathrm{m})\end{array}$ & $\begin{array}{c}\text { Curvature } \\
\mathscr{\psi}_{y}\left(10^{-3}\right)\end{array}$ & $\begin{array}{c}\text { moment } \\
M_{u}(\mathrm{kN}-\mathrm{m})\end{array}$ & $\begin{array}{c}\text { curvature } \\
\mathscr{\psi}_{u}\left(10^{-3}\right)\end{array}$ & \\
\hline FL1 & 14.6 & 0.7 & 48.19 & 3.25 & 53.02 & 30.5 & 9.4 \\
\hline FL2 & 27.91 & 0.56 & 134.16 & 3.00 & 140.71 & 21.0 & 7.0 \\
\hline FL3 & 28.00 & 0.43 & 177.73 & 2.63 & 182.11 & 17.0 & 6.5 \\
\hline FN1 & 17.36 & 0.14 & 44.57 & 3.75 & 47.27 & 32.0 & 8.5 \\
\hline FN2 & 28.19 & 0.29 & 145.03 & 3.50 & 147.25 & 22.0 & 6.3 \\
\hline FN3 & 27.77 & 0.34 & 172.51 & 2.50 & 172.59 & 14.8 & 5.9 \\
\hline
\end{tabular}

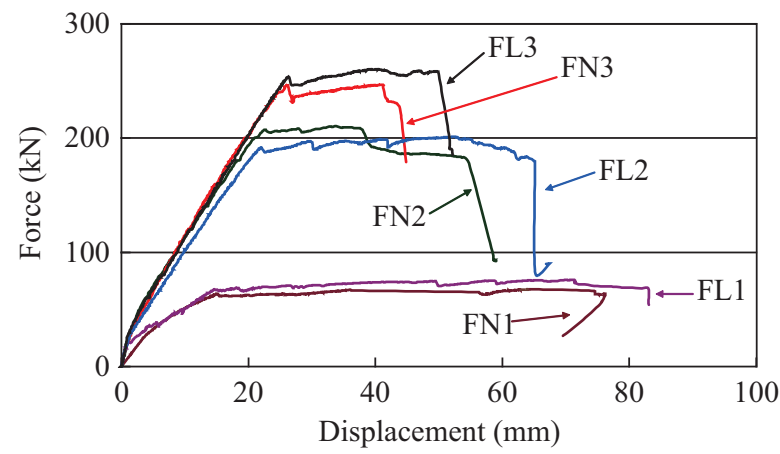

Fig. 7. Load-deflection curves of FL concrete beams.

associated with a reduction in the gradient of the curve, while the remaining two events are relatively no distinct but led to a reduction of the applied load. It is also found from the figure that the yielding loads as well as the ultimate loads of both the LWAC beams and the NWC beams are increased with the increase of reinforcement ratio.

The gradient of the load-deflection or moment-curvature curve is an indication of beam stiffness. It may be seen in Fig. 7 and Fig. 8 that prior to the peak, the stiffness of beam increases with an increase in the amount of tension reinforcement, and the LWAC beam performs slightly smaller stiffness than the corresponding NWC beam with same reinforcements.

\section{2) Ultimate Strength and Ductility}

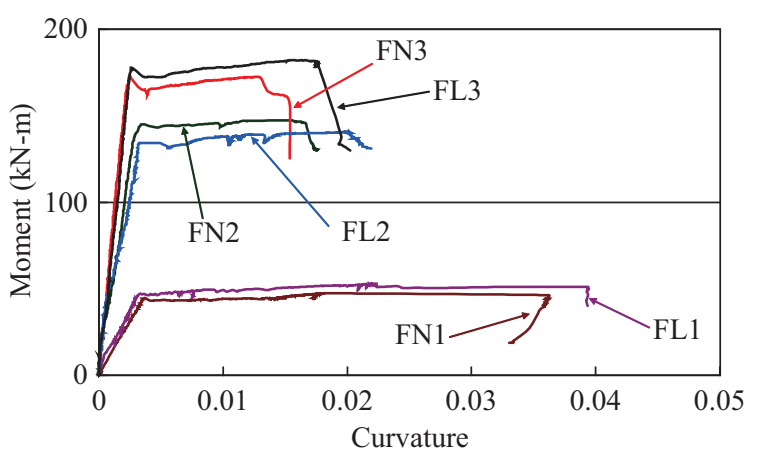

Fig. 8. Moment-curvature relationships of FL concrete beams.

The ultimate strengths attained by the beams can be determined either from the load-deflection curves of Fig. 7 or moment-curvature relationship of Fig. 8, the numerical values being listed in Table 5 and Table 6 . It may be seen from Table 5 that the LWAC beams with similar cross section and concrete strength can exhibit equivalent load capacities as the NWC beams, whereas, the amount of tension reinforcement has the noticeable influence on ultimate strength for obvious reasons. In all beams attainment of ultimate strength was accompanied by crushing of the concrete and a sudden drop in the applied load. The LWAC beams demonstrate larger ultimate deflections than those of the NWC beams, it may due to the smaller modulus of elasticity of LWAC.

It is found in Fig. 7 that the curves between yielding of steel 
Table 7. Comparison of mid-span deflections with the predictions of the ACI 318-05 Code.

\begin{tabular}{|c|c|c|c|c|c|c|}
\hline \multirow{2}{*}{ Beam Number } & \multicolumn{2}{|c|}{$\begin{array}{c}\text { Calculated mid-span } \\
\text { deflection }(\mathrm{mm})\end{array}$} & \multicolumn{2}{c|}{$\begin{array}{c}\text { Experimental mid-span } \\
\text { deflection }(\mathrm{mm})\end{array}$} & \multicolumn{2}{c|}{$\begin{array}{c}\text { Ratio of tested deflection and } \\
\text { calculated deflection }\end{array}$} \\
\cline { 2 - 7 } & at cracking & $\begin{array}{c}\text { at yielding } \\
\Delta_{c r, c}\end{array}$ & $\begin{array}{c}\text { at cracking } \\
\Delta_{c r, t}\end{array}$ & $\begin{array}{c}\text { at yielding } \\
\Delta_{y, t}\end{array}$ & $\frac{\Delta_{c r, t}}{\Delta_{c r, c}}$ & $\frac{\Delta_{y, t}}{\Delta_{y, c}}$ \\
\hline FL1 & 0.80 & 20.62 & 1.00 & 19.50 & 1.25 & 0.94 \\
\hline FL2 & 1.52 & 23.22 & 2.96 & 24.10 & 1.94 & 1.04 \\
\hline FL3 & 1.49 & 24.71 & 2.14 & 27.30 & 1.43 & 1.11 \\
\hline FN1 & 0.84 & 15.92 & 1.57 & 16.80 & 1.87 & 1.05 \\
\hline FN2 & 1.27 & 20.93 & 2.03 & 23.50 & 1.60 & 1.12 \\
\hline FN3 & 1.24 & 20.00 & 2.46 & 26.24 & 1.98 & 1.31 \\
\hline
\end{tabular}

and crushing in compression is nearly horizontal, indicating the ability of the beam to deform without losing strength. This is an indication of ductility. In this study, only sectional ductility is of concern. Ratio of curvature at crushing of concrete to that at yielding of steel gives the numerical value of ductility, known as ductility index. Table 6 presents the measured moment of beams and their analyzed curvature ductilities $\left(\mu_{\varphi}\right)$. It can be seen that the curvature ductility of LWAC beams and NWC beams ranges from 6.5 to 9.4 and 5.9 to 8.5 , respectively.

A close review of Fig. 7 and Fig. 8 clearly shows the effect of various parameters on ductility. It is seen that keeping other parameters constant, replacement of normal weight aggregate by lightweight aggregate has no noticeable influence on ductility. The most significant effect on ductility for both types of concrete beams is afforded by tensile reinforcement. A decrease in the amount of tensile reinforcement improves ductility (Table 6), this indicates that the LWAC beams exhibit the similar flexure behavior as that of the NWC beams.

\section{3) Comparison with Code Provisions}

The load-deflection response of the 6 beams at critical situation of first cracking and yielding are calculated analytically using the conventional flexural theory supported by the ACI 318-05 code. In the analysis, concrete is assumed to be elastic up to yielding of steel, and is represented by the rectangular stress block at ultimate. Material parameters like modulus of rupture $(f r)$, elastic modulus $(E)$, ultimate concrete strain $\left(\varepsilon_{c u}\right)$ etc. are taken from ACI 318 and ACI 213 provisions for NWC and LWAC, where are appropriate.

The calculated mid-span deflection at cracking and at yielding are presented and compared with the respective experimental deflection in Table 7. It can be seen that the experimental deflections at cracking for LWAC and NWC beams are on the average $54 \%$ and $82 \%$, respectively, more than the computed values obtained by using elastic flexural theory supported by ACI 318 (that is, $\Delta=0.1 M L^{2} / E I_{e}$ ). On the other hand, the experimental deflections at yielding for both concrete beams are on the average $10 \%$ more than the calculated deflections. This indicates that the elastic flexural theory sup- ported by ACI 318 code relatively underestimates the actual deflection for both LWAC and NWC beams.

\section{Size Effect of LWAC Beam}

\section{1) Flexural Strength and Deflection Analysis}

Results of load and deflection measured from different sizes of beams are given in Table 8. Stage I, II and III in Table 8 are referred to deflections at first cracking load, yielding load and ultimate load respectively. It can be seen from Table 8 that the ultimate load values of the LWAC beams measured from 400-, $550-$, and 700-mm high beams are about $99.9 \%, 96.2 \%$ and $94.1 \%$ of the corresponding values of NWC beams. This indicates that the use of LWAC may cause a higher reduction in the load-carrying capacity of a larger beam than of a small beam.

Fig. 9 and Fig. 10 demonstrate the load-deflection curves of various dimension of LWAC and NWC beams. It can be seen that the load and deflection at yielding strength and ultimate strength of both types of concrete beams increase as the specimen size increases. According to Bosco and Carpinteri [6] a non-dimension analysis was conducted herein, which correlates the load parameter $M / K_{I C} h^{3 / 2} b$ with the ultimate deflection ratio ${ }^{\mathrm{uu}} / \mathrm{s}$, where $\mathrm{M}$ is the ultimate moment at failure, KIC refers to the stress intensity factor determined by $K_{I C}=$ 0.0597 ( $\left.f \mathcal{c}^{\prime}\right) 0.75$ [10], $h$ is the beam depth, $b$ is the beam width, and $\Delta u$ stands for ultimate deflection. Such that, the Fig. 9 and 10 can be transformed into the plots in Fig. 11 and 12. As can also be seen in Table 8, the ultimate deflection-to-span ratio $(\Delta \mathrm{u} / \mathrm{s})$ decreases with an increase of dimension for both types of concrete beams. The ultimate deflection-to-span ratio varies from $1 / 115$ to $1 / 150$ as the effective depth $(d)$ increase from $300 \mathrm{~mm}$ to $600 \mathrm{~mm}$ for NWC beam, while the ratio varies from $1 / 84$ to $1 / 188$ for the corresponding LWAC beam. This reveals that the ultimate deflection-to-span ratio decreases $23 \%$ and $55 \%$ respectively for the NWC and the LWAC beams. This implies that the decay of ultimate deflection-to-span ratio of the LWAC beams due to the increase of beam size is more significant than that of the NWC beams. In addition, it is also found that the ultimate deflection-to-span ratio of LWAC 
Table 8. Results of size effect test.

\begin{tabular}{|c|c|c|c|c|c|c|c|}
\hline \multicolumn{2}{|c|}{ Beam number } & DN1 & DN2 & DN3 & DL1 & DL2 & DL3 \\
\hline \multicolumn{2}{|c|}{ Size $(b \times h)(\mathrm{mm})$} & $250 \times 400$ & $375 \times 550$ & $500 \times 700$ & $250 \times 400$ & $375 \times 550$ & $500 \times 700$ \\
\hline \multicolumn{2}{|c|}{ Span (mm) } & $\begin{array}{c}(d=300) \\
1800\end{array}$ & $\begin{array}{c}(d=450) \\
2700\end{array}$ & $\begin{array}{c}(d=600) \\
3600\end{array}$ & $\begin{array}{c}(d=300) \\
1800\end{array}$ & $\begin{array}{c}(d=450) \\
2700\end{array}$ & $\begin{array}{c}(d=600) \\
3600\end{array}$ \\
\hline \multicolumn{2}{|c|}{ Rebar arrangement } & $2 \# 4$ & $\begin{array}{l}1 \# 5 \\
4 \# 4\end{array}$ & $6 \# 5$ & $2 \# 4$ & $\begin{array}{l}1 \# 5 \\
4 \# 4\end{array}$ & $6 \# 5$ \\
\hline \multicolumn{2}{|c|}{ Reinforcement ratio (\%) } & 0.359 & 0.372 & 0.437 & 0.359 & 0.372 & 0.437 \\
\hline \multirow{2}{*}{ Stage I } & $\mathrm{P}(\mathrm{kN})$ & 40 & 80 & 200 & 50 & 100 & 150 \\
\hline & $\Delta(\mathrm{mm})$ & 0.5 & 0.2 & 1.5 & 0.6 & 0.6 & 1.6 \\
\hline \multirow{2}{*}{ Stage II } & $\mathrm{P}(\mathrm{kN})$ & 65.5 & 166 & 279 & 54.7 & 162 & 248 \\
\hline & $\Delta(\mathrm{mm})$ & 1.8 & 2.60 & 3.6 & 1.60 & 1.7 & 3.8 \\
\hline \multirow{2}{*}{ Stage III } & $\mathrm{P}(\mathrm{kN})$ & 82.8 & 199 & 307 & 82.7 & 191 & 289 \\
\hline & $\Delta(\mathrm{mm})$ & 15.7 & 19.8 & 23.9 & 21.44 & 16.4 & 19.2 \\
\hline \multicolumn{2}{|c|}{ Ductility $\left(\mu_{\Delta}\right)=\Delta_{u} / \Delta_{y}$} & 8.7 & 7.6 & 6.6 & 13.4 & 9.6 & 5.0 \\
\hline \multicolumn{2}{|c|}{ Deflection-to-span ratio $(\Delta \mathrm{u} / \mathrm{s})$} & $1 / 115$ & $1 / 136$ & $1 / 150$ & $1 / 84$ & $1 / 165$ & $1 / 188$ \\
\hline
\end{tabular}

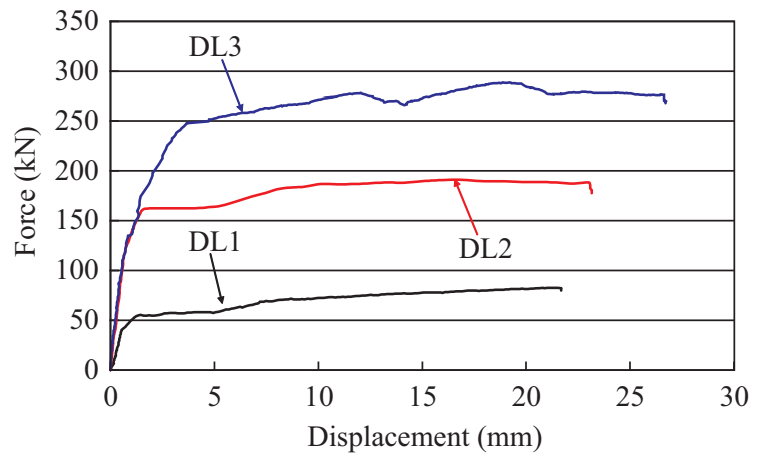

Fig. 9. Load-displacement curves of DL concrete beams.

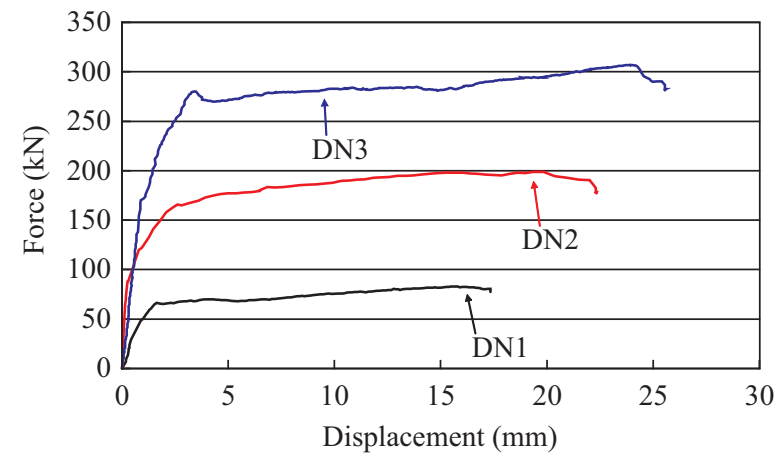

Fig. 10. Load-displacement relationships of DN concrete beams.

beam with effective depth $(d)$ of $600 \mathrm{~mm}$ has exceeded the limitation of $1 / 180$ by the ACI Code. This may be attributed to the absence of stirrups in the concrete specimens. However, it is still felt valid and necessary that the limitation of deflection for LWAC beam in the present building code may need further revisions by considering the size effect.

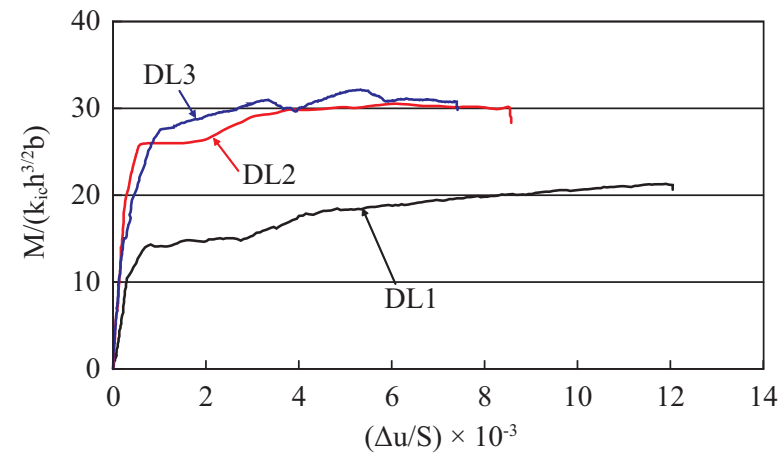

Fig. 11. Non-dimensional analysis for DL concrete beams.

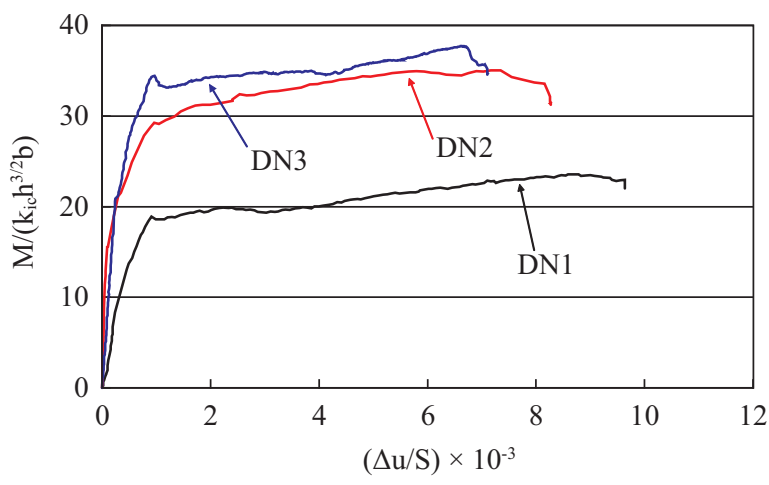

Fig. 12. Non-dimensional analysis for DN concrete beams.

\section{2) Ductility Analysis}

Fig. 13 shows the load-deflection curves in pair of different dimension of beams. It can be seen that for a given dimension and strength, the load versus displacement curves for both NWC specimen and LWAC specimen appear similar, but the former has a higher yielding strength and ultimate strength 


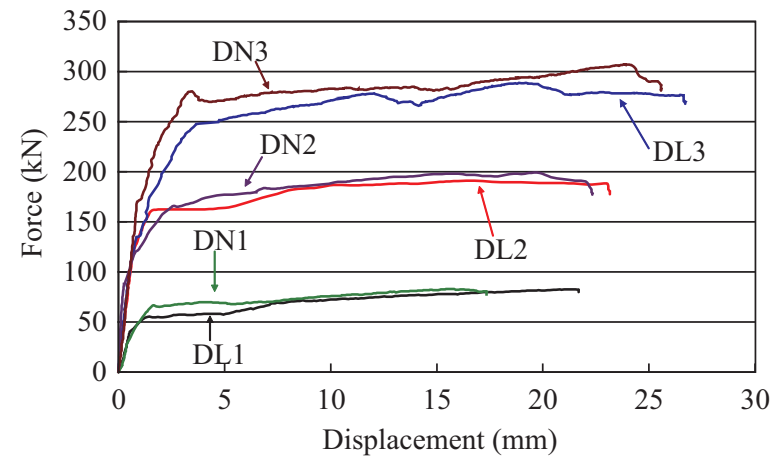

Fig. 13. Load-displacement curves of $D$ series concrete beams.

in each case. In addition, as can be seen in Table 8, the deflection at yielding strength and ultimate strength for LWAC beams appear lower than those of NWC beams. This may be attributed to the smaller toughness of aggregate which dominate the failure characteristic of beam. Lightweight aggregate concrete turns out weaker strength and more brittle.

It has been known that the deflection ductility, $\mu_{\Delta}$, in terms of ultimate deflection to yielding displacement, is highly correlated to the dimension of the specimen. As can be seen in Table 8 , the ductility of both types of concrete beams exhibit a reverse size effect, i.e., ductility decrease with the increase of size, namely, a larger beam performs less ductile. It is noticed that for those specimens with $\mathrm{d}=300 \mathrm{~mm}$ and $450 \mathrm{~mm}$, the ductility of LWAC beam turns out higher than those of NWC beams; however, for the specimen dimension with $\mathrm{d}=600 \mathrm{~mm}$, the ductility turns out less than that of NWC beam. After a regression analysis, it was found that the related equation for LWAC and NWC beams are $\mu_{\Delta}=-0.2787 \mathrm{~d}+21.937 ; \mathrm{R}^{2}=$ 0.9947 and $\mu_{\Delta}=-0.07 \mathrm{~d}+10.88 ; \mathrm{R}^{2}=0.9932$, respectively, as shown in Fig. 14. Specimens for both types of concretes perform closely linear in ductility $\left(\mu_{\Delta}\right)$ with respect to effective depth $(d)$, whereas, the ductility of LWAC beams decays more apparent than that of NWC beams. This indicates that the LWAC beam demonstrate a stronger reverse size effect than that of NWC beam.

\section{CONCLUSION}

An experimental study has been conducted to investigate the flexural behaviors and size effect of full size LWAC beam. The following conclusions can be made on the basis of the current experimental results of six flexural beams and 6 sizeeffect beams.

(1) The LWAC beams with similar cross-sections and concrete strengths can exhibit load capacity equivalent to that of the NWC beams, but demonstrate larger ultimate deflections than those of NWC beams.

(2) The variation pattern of curvature ductility of LWAC beams, same as that of $\mathrm{NC}$ beams, decreases with an increase of the reinforcement ratio, indicating that the LWAC

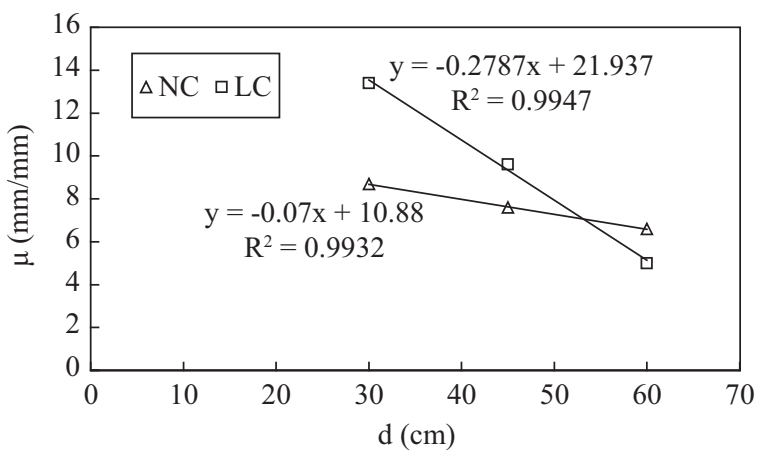

Fig. 14. Ductility versus dimension of concrete beams.

beams exhibit similar flexural behavior as that of NWC beams.

(3) The test results reveal that the deflections at the stage of cracking for both LWAC and NWC beams are larger than theoretically calculated values (from $25 \%$ to $98 \%$ ). On the other hand, the measured deflections at the yielding stage for both types of concrete beams are on the average $10 \%$ more than the calculated deflections. This indicates that the elastic flexural theory adopted by ACI 318 code relatively underestimates the actual deflections for both LWAC and NWC beams.

(4) The loads and deflections corresponding to the yielding strength and ultimate strength of the LWAC and NWC beams increase as the specimen size increases.

(5) The ultimate deflection-to-span ratio $(\Delta \mathrm{u} / \mathrm{s})$ decreases with an increase of the dimension for both types of concrete beams. When the effective depth increases from $300 \mathrm{~mm}$ to $600 \mathrm{~mm}$, the ultimate deflection-to-span ratios decrease about $23 \%$ and $55 \%$ respectively for the NWC and LWAC beams. This implies that the decay of ultimate deflection ratio of the LWAC beams due to the increase of beam size is more significant than that of the NWC beams. Moreover, the measured ultimate deflection-to-span ratio of LWAC beam with an effective depth $(d)$ of $600 \mathrm{~mm}$ has exceeded the limitation of $1 / 180$ by the ACI Code. This indicates that the limitation of deflection-to-span in the present building code may need further revisions by considering the size effect.

\section{ACKNOWLEDGMENTS}

The authors are grateful for the financial supports from the Architecture and Building Research Institute in Taiwan. Professor Fuh-Min Fang is appreciated for his editorial assistance.

\section{REFERENCES}

1. Ahmad, S. H. and Barker, R., "Flexural behavior of reinforced highstrength lightweight concrete beams," ACI Structural Journal, Vol. 88, No. 1, pp. 69-77 (1991).

2. Ahmad, S. H. and Batts, J., "Flexural behavior of double reinforced high-strength lightweight concrete beams with web reinforcement," $A C I$ 
Structural Journal, Vol. 88, No. 3, pp. 351-358 (1991).

3. Bardhan-Roy, B. K., "Lightweight aggregate concrete in UK," International Symposium on Structural Lightweight Aggregate Concrete, Sandefjord, Norway, pp. 52-69 (1995).

4. Barnes, B. D., Diamond, S., and Dolch, W.L., "Micro morphology of the interfacial zone around aggregate in Portland cement mortar," Journal of the American Ceramic Society, Vol. 62, No. 1-2, pp. 21-24 (1979).

5. Bazant, Z. P. and Planas, J., Fracture and Size Effect in Concrete and Other Quasibrittle Materials, CRC Press LLC, United States (1997).

6. Bosco, C., Carpinteri, A., and Debernardi, P. G., "Minimum reinforcement in high-strength concrete," Journal of Structural Engineering, Vol. 116, No. 2, pp. 427-437 (1990).

7. Carpinteri, A., Applications of Fracture Mechanics to Reinforced Concrete, Routledge, United Kingdom (1992).

8. Chen, H. J., "Research on the lightweight aggregate made with reservoir sediment and the lightweight aggregate concrete," Report of NSC, E-2000 (2000). (in Chinese)

9. Helgesen, K. H., "Lightweight aggregate concrete in Norway," International Symposium on Structural Lightweight Aggregate Concrete, Sandefjord, Norway, pp. 70-82 (1995).

10. John, P. and Shah, S. P., "Fracture mechanics analysis of high strength concrete," ASCE Journal of Materials, Vol. 1, No. 4, pp. 185-198 (1989).

11. Lo, T. Y. and Cui, H. Z., "Effect of porous lightweight aggregate on strength of concrete," Materials Letters, Vol. 58, No. 6, pp. 916-919 (2004).

12. Swamy, R. N. and Lambert, G. H., "Flexural behavior of reinforced beams made with fly ash coarse aggregates," The International Journal of Cement Composites and Lightweight Concrete, Vol. 6. No. 3, pp. 189-200 (1984).

13. Yen, T., "Potentiality and strategy of the development of artificial lightweight aggregate in Taiwan," Proceeding of the 2nd Conference on Lightweight Aggregate Concrete, National Chung-Hsing University, Taiwan, pp. 1-20 (2005). (in Chinese)

14. Yen, T., "Production of reservoir silt aggregate and industrial application of lightweight-aggregate concrete," Report of Research Project, NSC, Taiwan (2006). (in Chinese)

15. Zhang, M. H. and Gjorv, O. E., "Microstructure of the interfacial zone between lightweight aggregate and cement paste," Cement Concrete Research, Vol. 20, No. 4, pp. 610-618 (1990).

16. Zhou, F. P., Balendran, R. V., and Jeam, A. P., "Size effect on flexural, splitting tensile and torsional strength of high-strength concrete," Cement and Concrete Research, Vol. 28, No. 12, pp. 1725-1736 (1998). 